\title{
Budd-Chiari Syndrome as a Manifestation of Antiphospholipid Antibody Syndrome during Oral Contraceptive Therapy: More to Think About
}

\author{
ladevaia M*, Del Prete A, Cotticelli G, De Sio I, Niglio A and Loguercio C \\ Department of Internistica Clinica e Sperimentale "F.Magrassi e A.Lanzara”, Hepatogastroenterology Unit, Second University of Naples, Naples, Italy
}

\begin{abstract}
The association of Budd-Chiari Syndrome (BCS) and Antiphospholipid Antibody Syndrome (APS) has been previously described in literature. We report the case of a 46-year-old woman who was admitted to our Unit of Hepatology for upper abdominal quadrant pain, asthenia and edema of the left upper arm. Her familiar history told about predisposition to Systemic Lupus Erythematosus (SLE) whereas her personal story showed a continuous use of oral contraceptives during the six years preceding diagnosis and the absence of episodes of obstetric complications. At the admission, a Doppler Ultrasound examination showed complete thrombosis of venous axis of the left upper arm and thrombosis of subclavian artery (with the aspect of "subclavian steal syndrome"). Abdominal ultrasonography revealed hepatic lesions (characterized by an abdominal Computed Tomography as ischemic injuries) at seventh and eighth segments and the presence of significant amount of ascites. Abdominal and thoracic Computed Tomography confirmed pleural effusion and pointed out a radiologic pattern of Budd-Chiari Syndrome. To verify the presence of concomitant pericardial effusion, an echocardiogram was performed. It allowed reaching the diagnosis of polyserositis. In order to investigate all potential causes of thrombotic diathesis, specific laboratory tests were performed. Normal level of protein C, S and antithrombin II, absence of JAK-2 mutation and negativity of Ham's test were observed. Positivity was found for anti-SSA (60 kDa) and for antibodies routinely tested for Antiphospholipid Antibody Syndrome (APS), i.e. Lupus-Anticoagulant, Anticardiolipin and Beta2- Glycoprotein I. After the introduction of oral anticoagulant and diuretics a significant improvement of clinical condition of the patient was reached. To conclude, the exact role of oral contraceptives as triggering factor of an undetected APS need to be emphasize, as well as the potentiality of this disease to evolve in a "to happen" SLE in patients with positive familiarity for autoimmune diseases.
\end{abstract}

\section{Introduction}

Budd-Chiari Syndrome (BCS) is a spectrum of disease states, including anatomic abnormalities and hypercoagulable disorders, resulting in hepatic venous outflow occlusion from the small hepatic veins up to where the inferior vena cava enters the right atrium [1]. Contrary to Asia and Africa, where BCS is caused primarily by an obstructing membranous web, BCS in the western world is considered a thrombotic complication of an underlying hypercoagulable state [2]. BCS may be classified as primary or secondary, depending on the underlying process [3].

A small number of cases about association of BCS and Antiphospholipid Antibody Syndrome (APS) have been reported in literature [4-7]. APS is defined by thrombotic events and/or obstretic complications and the presence of Antiphospholipid Antibodies (APAs), including Lupus Anticoagulant (LAC), Immunoglobuline (Ig) $\mathrm{G}$ or IgM anticardiolipin (aCL) and IgG/IgM anti-Beta-2 glycoprotein I antibodies (anti-B2GPI) [8]. LACS are identified by clot-based coagulation tests, whereas aCL and anti-B2GPI antibodies by EnzymeLinked Immunosorbent Assay (ELISA). To confirm the diagnosis of APS, antibodies should be retested at least 12 weeks after initial positive result. The mechanism of thrombosis in APS patient is still unknown. APAs seem to interfere with endogenous anticoagulant pathways, binding and activation of platelets, expression of adhesion molecules and tissue factor on endothelium and activation of the complement cascade. LAC is known to inhibit the conversion of prothrombin to thrombin, paradoxically inducing an increased tendency to thromboembolic events, despite in vitro prolongation of the activated Partial Thromboplastin Time (aPTT) [9].

\section{Case-Report}

A 46 years-old Caucasian woman was admitted to our Unit of Hepatology for upper abdominal quadrant pain, asthenia and edema of the left upper arm. Her family story revealed a sister with diagnosis of Systemic Lupus Erythematosus (SLE), whereas her personal story told about a continuously use of oral contraceptives during the six years preceding diagnosis, no smoking habits or alcohol abuse and absence of episodes of obstetric complications. The patient had received diagnosis of uterin leiomyoma several years before.

On admission, in addition to persistence of abdominal pain and edema of the left arm, physical examination showed hepatomegaly, mild ascites and pleuric effusion. Laboratory data pointed out as follows: hypocromic and mycrocitic anemia (Hb 11,8 gr/dL, MCV: 79,8 fl), low platelet count $\left(118,000 / \mathrm{mm}^{3}\right)$, elongation of activated partial thromboplastin time (aPTT: $77 \mathrm{sec})$, hyperfibrinogenemia $(834 \mathrm{mg} /$ $\mathrm{dL})$, hyperferritinemia $(483 \mathrm{mg} / \mathrm{dL})$, low level of albumin $(2,4 \mathrm{gr} / \mathrm{dL})$ and cholinesterase (691 UI/l), hepatocytolysis (AST $57 \mathrm{UI} / \mathrm{l}$, ALT 57 UI/l), cholestasis (GGT $68 \mathrm{UI} / \mathrm{l}, \mathrm{FA}: 334 \mathrm{UI} / \mathrm{l}$ ), high hemosedimentation velocity and high level of C-reactive protein. Viral markers and renal function tests were negative.

*Corresponding author: Maddalena D. Iadevaia, Department of Internistica Clinica e Sperimentale "F.Magrassi e A.Lanzara”, Hepatogastroenterology Unit, Second University of Naples, via Pansini 5, 80131, Naples, Italy, Tel: +39.333.16.47.824; Fax:+39.081.566.6736; E-mail: maddalenaiadevaia@hotmail.com

Received December 09, 2012; Accepted September 23, 2013; Published September 30, 2013

Citation: ladevaia M, Del Prete A, Cotticelli G, De Sio I, Niglio A, et al. (2013) BuddChiari Syndrome as a Manifestation of Antiphospholipid Antibody Syndrome during Oral Contraceptive Therapy: More to Think About. J Liver 2: 129. doi:10.4172/21670889.1000129

Copyright: (c) 2013 ladevaia M, et al. This is an open-access article distributed under the terms of the Creative Commons Attribution License, which permits unrestricted use, distribution, and reproduction in any medium, provided the original author and source are credited. 
Doppler Ultrasound examination showed complete thrombosis of venous axis of the left upper arm (including subclavian, axillary and humeral veins) and thrombosis of subclavian artery (with the ultrasound aspect of "subclavian steal syndrome"). Abdominal ultrasonography revealed the presence of hepatic lesions (later characterized by an abdominal Computed Tomography as ischemic injuries) at seventh and eighth segments of an enlarged liver and the presence of significant amount of ascites. Abdominal and thoracic Computed Tomography confirmed the pleuric effusion and pointed out a radiologic pattern of Budd-Chiari Syndrome. To verify the presence of concomitant pericardial effusion, an echocardiogram was performed, which allowed us to diagnose a condition of polyserositis. Citology of fluids obtained by paracentesis and thoracentesis was negative for malignant cells, whereas the analysis of their chemical-physical characteristics revealed a transudate and exudate, respectively.

In order to investigate all potential causes of thrombotic diathesis, further laboratory specific tests were performed. Normal level of protein $\mathrm{C}$, protein $\mathrm{S}$, antithrombin II, homocysteine, absence of JAK2 mutation and negativity of Ham's test (specific for paroxysmal nocturnal hemoglobinuria-PNH) were observed. Positivity was found for anti-SSA $(60 \mathrm{kDa})$ and for antibodies routinely tested for diagnosis of Antiphospholipid Antibody Syndrome (APS), i.e. LAC (Lupus-Anticoagulant), aCL (anticardiolipin) and Beta2-GPI (Beta2glycoprotein I) (Table 1). Even if patient did not fulfill criteria for SEL, on consideration of her positive familiarity for this disease, auto antibodies were tested.

During the observation, a diagnosis of autoimmune chronic thyroiditis was reached, basing on unknown condition of hypothyroidism (TSH $36 \mathrm{UI} / \mathrm{l}$ ). Replacing treatment with thyroid hormones was started.

Symptomatic treatment with heparin (8000 UI twice daily subcutaneously) was suddenly established at the admission, later supplemented and then replaced with oral anticoagulants. Diuretic therapy was also prescribed and allowed to get a complete remission of pleural and abdominal effusions at the moment of discharge from hospital. At that time, the patient was sent home with diagnosis of APS, which was confirmed by the repetition of laboratory tests after a distance of twelve weeks from the first assessment (according to guidelines). She has been constantly visited as outpatient to better assess the anticoagulant therapy and regularly follow her clinical course.

\section{Discussion}

Budd-Chiari Syndrome (BCS) is a rare but potentially lifethreatening disorder caused by hepatic venous obstruction, distinct from cardiac causes of hepatic congestion or sinusoidal

\begin{tabular}{|c|c|c|}
\hline $\begin{array}{l}\quad \text { Lupus Anticoagulant (LAC) } \\
\text { - } \quad \text { LAC screen Ratio } \\
\text { - } \\
\text { LAC ratio N }\end{array}$ & $\begin{array}{l}\text { Mildly positive } \\
\text { Mildly positive }\end{array}$ & $\begin{array}{l}1.96(0.8-1.2) \\
1.36(0.8-1.2)\end{array}$ \\
\hline $\begin{array}{ll} & \text { Anticardiolipin ( } \mathrm{aCL} \text { ) } \\
- & \lg \mathrm{g} \\
- & \operatorname{lgM}\end{array}$ & $\begin{array}{l}\text { Mildly positive } \\
\text { Mildly positive }\end{array}$ & $\begin{array}{l}32 \mathrm{GPL} \\
17 \mathrm{MPL}\end{array}$ \\
\hline $\begin{array}{ll} & \text { Beta2- Glicoprotein I (Beta2-GPI) } \\
- & \operatorname{lgG} \\
& \operatorname{lgM}\end{array}$ & $\begin{array}{l}\text { Positive } \\
\text { Negative }\end{array}$ & $\begin{array}{l}25 \mathrm{UI} / \mathrm{I} \\
0,9 \mathrm{UI} / \mathrm{I}\end{array}$ \\
\hline
\end{tabular}

Table 1: A mildly positivity was found for $L A C$ and $a C L$ (both $\lg G$ and $\lg M$ ), a clearly positivity for Beta2-GPI ( $\operatorname{lgG}$ ). These results were confirmed at a second repetition after a distance of twelve weeks from the first assessment. obstruction syndrome (formerly known as veno-occlusive disease) [2]. Several condition have been implicated in its pathogenesis, including myeloproliferative disorders, oral contraceptives, pregnancy, Paroxysmal Nocturnal Hemoglobinuria, the presence of lupus anticoagulant and others [10]. The combination of recurrent thrombosis and antiphospholipid antibodies in patients without features of SLE is called primary Antiphospholipid Antibodies Syndrome [11].

In our patient two risk factors for the development of BCS were present: the use of oral contraceptives and positive familiarity for SEL represented, in fact, two "predisposing" conditions. In order to progressively confirm or excludeall potential causes of APS, appropriated tests were performed: JAK2 mutation for myeloproliferative disorders and Ham's test for PNH. We also consider a paraneoplastic syndrome as a potential cause of thromboembolic state (endoscopic examinations of gastrointestinal tract were performed, together with an accurate gynecological evaluation and determination of neoplastic markers).

Venous thromboembolism is the most common clinical presentation and affects between $30-70 \%$ of APS patients [12]. The deep veins of the extremities are most commonly affected, followed by axillary, retinal, hepatic and cerebral venous sinus thrombosis. Other clinical manifestation includes hepatomegaly, right upper quadrant pain, and abdominal ascites. Specifically, our patient presented all aforementioned conditions on admission, but in addition a polyserositis and chronic thyroiditis could be observed, indicating for the patient an "autoimmune" predisposition. The patient, however, did not fulfill criteria for diagnosis of SLE.

\section{Conclusion}

To conclude, the case we reported should lead clinicians to answer two clinical questions: 1) to consider the possible role of APS as a prodromic condition of a " to happen" SLE in patient with positive familiarity for this disease; 2) to determine what factors are involved in inducing a sudden development of thrombosis in this class of patients.

Oral contraceptive therapy is significantly associated with the development of BCS, but its real burden as triggering factor in inducing appearance of an undetected APS is still unclear. Nothing is known about these aspects, so it needs to be investigated.

\section{References}

1. Horton JD, San Miguel FL, Membreno F, Wright F, Paima J, et al. (2008) BuddChiari syndrome: illustrated review of current management. Liver Int 28: 455466 .

2. Rav-Acha M, Gur C, llan Y, Verstandig A, Eid A (2004) Budd-Chiari syndrome: updated treatment modalities. Harefuah 143: 372-376, 389.

3. Bogin V, Marcos A, Shaw-Stiffel T (2005) Budd-Chiari syndrome: in evolution Eur J Gastroenterol Hepatol 17: 33-35.

4. Pomeroy C, Knodell RG, Swaim WR, Arneson P, Mahowald ML (1984) BuddChiari syndrome in a patient with the lupus anticoagulant. Gastroenterology 86: 158- 161.

5. Averbuch M, Levo $Y$ (1986) Budd-Chiari syndrome as the major thrombotic complication of systemic lupus erythematosus with the lupus anticoagulant. Ann Rheum Dis 45: 435-437.

6. Van Steenbergen W, Beyls J, Vermylen J, Fevery J, Marchal G, et al. (1986) 'Lupus' anticoagulant and thrombosis of the hepatic veins (Budd-Chiar syndrome). Report of three patients and review of the literature. J Hepatol 3: 87-94.

7. Ouwendijk RJ, Koster JC, Wilson JH, Stibbe J, Lameris JS, et al. (1994) BuddChiari syndrome in a young patient with anticardiolipin antibodies: need for prolonged anticoagulant treatment. Gut 35: 1004-1006.

8. Sangle NA, Smock KJ (2011) Antiphospholipid antibody syndrome. Arch Patho Lab Med 135: 1092-1096. 
Citation: Iadevaia M, Del Prete A, Cotticelli G, De Sio I, Niglio A, et al. (2013) Budd-Chiari Syndrome as a Manifestation of Antiphospholipid Antibody Syndrome during Oral Contraceptive Therapy: More to Think About. J Liver 2: 129. doi:10.4172/2167-0889.1000129

Page 3 of 3

9. Boey ML, Colaco CB, Gharavi AE, Elkon KB, Loizou S, et al. (1983) Thrombosis in systemic lupus erythematosus: striking association with the presence of circulating lupus anticoagulant. Br Med J (Clin Res Ed) 287: 1021- 1023

10. Zimmerman MA, Cameron AM, Ghobrial RM (2006) Budd-Chiari syndrome. Clin Liver Dis 10: 259-273.
11. Alarcón-Segovia D, Sanchez-Guerrero J (1989) Primary antiphospholipid syndrome. J Rheumatol 16: 482-488. Erratum in: J Rheumatol 16: 1014.

12. Gastineau DA, Kazmier FJ, Nichols WL, Bowie EJ (1985) Lupus anticoagulant an analysis of the clinical and laboratory features of 219 cases. Am J Hemato 19: $265-275$. 